\title{
DILEMMA OF MUSLIM WOMEN REGARDING DIVORCE IN SOUTH AFRICA
}

N Gabru*

\section{Introduction}

Over the years South African courts have been faced with many interesting and complex issues regarding the Muslim ${ }^{1}$ community, ${ }^{2}$ particularly, in respect of the position of Muslim spouses.

Section 15(3) of the Constitution, ${ }^{3}$ in guaranteeing freedom of religion, provides that the state may pass legislation recognising systems of personal and family law, but subject to the values entrenched in the Constitution.

Even though a number of years have passed under the new dispensation and despite various endeavours on the part of the Muslim communities to seek legal recognition of aspects of the Islamic family law, no legal recognition has as yet been granted. ${ }^{4}$

As such, questions relating to the validity of marriages and divorces, the custody and care of children are of major significance. Problems relating to the above

* BCom LLB (PU for CHE). Lecturer North-West University (Potchefstroom Campus) South Africa. Adaptation of a paper delivered at the Law Teachers Conference, Windhoek, Namibia, July 2003.

1 Refers to persons that follow the religion of Islam.

2 See Ismail v Ismail 19831 SA 1006 (W); Ryland v Edros 19972 SA 690 (C); Amod v Multilateral Motor Vehicle Accidents Fund (Commission for Gender Equality Intervening) 19942 SA 1319 (A), hereinafter referred to as the Amod case; Juleiga Daniels v Robin Grieve Campbell (unrep CPD case no 1646/01 of 24 June 2003). Hereinafter referred to as the Daniels case.

3 The Constitution of the Republic of South Africa Act 1996, hereinafter referred to as the Constitution.

4 Alinaam http://www.alinaam.org.za/misc/mpl-const.htm 19 May. 
have arisen with regularity in recent years in the context of family law and the law of succession. ${ }^{5}$

\section{At present even though the $A m o d^{6}$ and Daniels ${ }^{7}$ cases may be regarded as landmark decisions with regards to the rights of Muslims in South Africa, ${ }^{8}$ its effects are limited. No recognition has been given to Muslim marriages. ${ }^{9}$}

\section{From practical experience ${ }^{10}$ it is often found Muslim persons resort to a dual legal identity to pursue their conduct of affairs - one Islamic, another the secular legal}

5 See $\mathrm{n} 2$ above.

6 See $\mathrm{n} 2$ above.

7 See $n 2$ above.

8 In the Amod case it is only the claim of a surviving spouse (not married in terms of a valid civil marriage) for loss of support that has been extended to spouses married in terms of the unrecognised Islamic law. The Cape High Court ruled in the Daniels case that legislation that disinherits a bereaved spouse married in terms of Islamic only and whose husband or wife dies intestate (in terms of the Intestate Succession Act 81 of 1987) is unconstitutional. The case has been confirmed by the Constitutional Court. The practical effect of this will be that Muslim spouses may inherit as intestate heirs from the estate of their deceased spouses and also claim maintenance in terms of the Maintenance of Surviving Spouse Act 27 of 1990, if they were in a monogamous marriage. Claiming maintenance from the estate of the deceased spouse is limited in terms of the Shari'ah, and differs from the maintenance due to a wife as a result of divorce. It is important to distinguish between revocable and irrevocable divorces, as this also has an effect on the maintenance that can be claimed. A revocable divorce is where the woman was divorced, after consummation, without her giving up any money for the purpose of divorce. The divorce must have been the first or second pronouncement of divorce. In the case of the irrevocable divorce, such as if it were the third divorce, of if she paid something to get him to divorce her or if it were a waiting period due to nullification of the marriage contract, and it is not a waiting period of divorce, in these cases, she does not inherit from the husband. Thus the maintenance that a spouse may claim, in terms of the courts decision in the Daniels case, can in some instances be in conflict with the Shari'ah. In terms of Shari'ah, if the surviving spouse is a woman, is allowed to claim maintenance while she is in her waiting period. Thus the question arises as to whether she will be allowed to claim for maintenance beyond this period. It is submitted that this is open to interpretation. Shari'ah or Islamic law, covers all aspects of the Islamic faith, including beliefs and practices. Shari'ah is derived primarily from the Qur'an (the primary source of Islamic values). Muslims believe that it is the exact word of Allah (One Supreme Being) revealed to the prophet Muhammad through the angel Gabriel) and the sunnah (what the prophet [peace be upon him] did, said or tacitly approved of) as known from the hadith (documented narrations of the prophet) and also through ijtihad (interpretation of new cases through inferential analysis from the primary source of Islamic law and the sunnah by Muslim scholars). To be academically valid, the presentation of Islamic perspectives on any issue must be based upon these sources, particularly the first two. See in this regard Doi Shari'ah 2-111. See also text to $n 22$.

9 It is to be noted that in May 2000, the SALC Project Committee 59 on Islam Marriages and Related Matters released Issue Paper 15 containing initial law reform proposals for the recognition of Islamic Marriages. SALC Islamic Marriages and Related Matters http://www.law.wits.ac.za/salc/issue/ip15. pdf (Issue Paper 15) 1 Nov. 
system. As a result of this dual legal identity, it is not uncommon to find that a Muslim person concludes a marriage in terms of Shari'ah ${ }^{11}$ only, or both in terms of Shari'ah and in terms of the South African law. On a daily basis people enquire about the dissolution of Islamic marriages. Unfortunately more often than not, such queries are posed by women who are married in terms of Shari'ah only. Such women are prejudiced by the non-recognition of their Islamic marriage, due to the fact that they are unable to institute any action in a South African court of law for the dissolution of their marriage, and neither can they claim any maintenance from their spouse during the period in which they remain to be solely within the Islamic marriage.

In this article the dissolution of marriages as well as Muslim women's rights to maintenance is briefly discussed with a view to making certain suggestions for South Africa.

\section{Dissolution of marriages}

\subsection{Dissolution of marriages in South Africa}

Marriages in South Africa may be dissolved by the death of one of the spouses or by divorce. The grounds for divorce as well as the burden of proof are set out and regulated by the Divorce Act 70 of $1979 .{ }^{12}$ In terms of this Act, a decree of divorce will be granted by a court of law. The Divorce Act does not apply to persons married in terms of Shari'ah only. ${ }^{13}$ The courts have stated that the non-

10 The writer is a practicing attorney advising inter alia Muslim clients.

11 See $\mathrm{n} 6$ above.

12 Hereinafter referred to as the Divorce Act. A full discussion of the grounds for divorce falls beyond the scope of this article. See also Hahlo Husband and Wife; Robinson, Human and Boshoff Familiereg; Van der Vyver and Joubert Persone- en Familiereg.

13 The reason for this is that there is not a "marriage" in terms of the law to be dissolved. See $s$ 5(a) of the Divorce Amendment Act 95 of 1996 and Moosa 1999 DR 33-37. 
recognition of Islamic marriages is based on the fact that such marriages are potentially polygamous. ${ }^{14}$

\subsection{Dissolution of marriages in Islam}

Marriage in Islam is a sanctified bond that should not be broken except for compelling reasons. ${ }^{15}$ Islam recognises divorce, yet it discourages it by all means. ${ }^{16}$ Islam recognises the right of both partners to end their matrimonial relationship. ${ }^{17}$ Islam grants the husband the right of divorce ${ }^{18}$ and also grants the wife the right to request and apply to dissolve the marriage through what is known as Khula, ${ }^{19}$ the woman also has the right to a delegated divorce. ${ }^{20}$ If the husband dissolves the marriage by divorcing his wife, he cannot retrieve any of the gifts he has given her. ${ }^{21}$ In some cases, the wife has no option but to claim for a divorce because of some compelling reason such as cruelty by the husband and desertion without reason. In such cases the marriage is dissolved in terms of an Islamic judicial process known as Faskh. ${ }^{22}$ Islam further makes provision for

14 Ismail v Ismail $19831 \mathrm{SA} 1006(\mathrm{~W})$.

15 Cassim 1999 Codicillus 1-2. See also Azeem Women in Islam 20.

16 This can be seen from the strong deterrents like dower, and the intervening marriage known as Halala. A full discussion of dowry falls beyond the scope of this article. For a full discussion on dowry refer to Doi Shari'ah 158-164.

17 Rautenbach and Goolam (eds) Legal Pluralism 67.

18 The most common form of divorce initiated by males is known as talaq ("letting go free"), which involves a category of statements and Islamically defined formats by the husband that he divorces his wife. Very strict rules have been established in Islamic law to prevent misuse of the husband's right to divorce his wife. A detailed discussion of talaq falls beyond the scope of this article. For a detailed discussion of talaq see Ghazali Marriages in Islam 84-88; Doi Shari'ah 168-188.

19 Khula refers to the agreement between the husband and the wife whereby the wife may surrender her claim to unpaid dowry (mahr) or returns the full or partial amount of paid dowry in order to induce the husband to agree to divorce. In this regard the Qur'an states in ch $2 \mathrm{v}$ 229: "If the wife decides to end the marriage, she may return the marriage gifts to her husband. This is regarded as a fair compensation for the husband who is keen to keep his wife, while she chooses to divorce him. Thus "there is no blame on either of them, if she gives something for her freedom." See also Ghazali Qadaya al Mar'aa bin al Taqaleed al Rakida wal Wafida 178-180. A full discussion of Khula falls beyond the scope of this article, and for further reference see Rautenbach and Goolam (eds) Legal Pluralism 70; and Doi Shari'ah 168-188.

20 See Rautenbach and Goolam (eds) Legal Pluralism 67.

21 Holy Qur'an ch 4 v 20.

22 Legal annulment of the marriage. 
the "reasonable maintenance" of divorced women. ${ }^{23}$ Focus is now drawn to the discouragement of divorce in Islam. The Prophet of Islam (peace be upon him) is reported to have said "divorce is the most hateful of all permitted acts to God". ${ }^{24}$ The Qur'an in chapter 4 verse 34-35 gives advice to the spouses whose partners are in the wrong, in an effort to save the marriage, and the parties may separate peacefully and amicably if all reasonable measures fail.

In short, Islam has offered the Muslim woman some unequalled rights: she can request to end the marriage through khula and she can sue for a divorce using the Islamic judiciary. As such, it is submitted that in the spirit and ethos of Islam, a Muslim woman can never become chained by a recalcitrant husband.

23 Holy Qur'an ch 2 v 241 and also ch 2 v 236-237. See $n 8$ above.

24 Islamic Society http://www.unn.ac.uk/societies/islamic/about/women/judochri.htm 19 May. 


\subsection{The effect of the non-recognition of Islamic marriages}

The non-recognition of Islamic marriages has the effect that a person married in terms of Shari'ah only, has no right to approach a court of law for a decree of divorce. Muslim clerics often suffer to resolve marital conflicts and fail to enforce financial duties ${ }^{25}$ of the males towards their Islamic spouses. Also, though some Islamic institutions in South Africa have internal mechanisms to conclude a faskh and have executed such terminations, there has been no consensus on format and procedure. In some cases, the male spouses refused to acknowledge the validity of such a marital annulment since they rejected the Islamic institution or its Islamic authority over the marriage for various factors. This attitude has in turn resulted in a custom in South Africa, whereby Muslim husbands refuse to divorce their wives in terms of Islamic law. ${ }^{26}$ They further refuse to reach a settlement agreement so that the wife may make use of her right to request a Khula to obtain a divorce. The wife in turn cannot make use of the South African judiciary to obtain a divorce, because of the non-recognition of her marriage. The result of this unwillingness on the part of the husband, and the non-recognition of the marriage in terms of South African law lead to the gross infringement of Muslim women's fundamental rights ${ }^{27}$ as entrenched in the Constitution. This may be best explained by a practical example.

A Muslim woman entered into a marriage with a Muslim man early in 2001. The marriage was entered into in terms of the Shari'ah. Thus no civil marriage was registered in terms of the South African law. The husband was about 34 years of age, and was a chartered accountant by profession. Soon after the marriage, the wife came to find out that her husband was in actual fact 39 years of age, and did

25 An example of such a duty is the duty of a husband to provide maintenance to his wife and children.

26 Interview conducted with Mufti Minty of Klerksdorp on 28 May 2003.

27 It is submitted that the right to freedom and security of the person and the right to freedom of association, is infringed upon by the husband by holding the wife captive in a marriage that has irretrievably broken down. This is torture, and limits the wife's freedom of association due to the fact that the wife may not enter into another Islamic marriage until and unless the 
not have any profession what so ever. In fact her husband was unemployed. The burden, in this case, of maintaining the family as well as the extended family ${ }^{28}$ fell entirely on the wife. A burden, which is in direct conflict with Islamic law. ${ }^{29}$

What complicated matrimonial matters further was the fact that the husband physically abused his wife during the marriage. This together with other factors ${ }^{30}$ caused a significant strain on the marriage and the marriage eventually broke down irretrievably late in 2001. The wife left the matrimonial home of her husband and requested a divorce from him.

The husband refuses to divorce the wife in terms of the Islamic law. ${ }^{31}$ The wife could unfortunately not make use of her right to pronounce the divorce, because this right was not agreed upon in the marriage contract, ${ }^{32}$ and the husband refused to reach a settlement in terms of which the wife may obtain a divorce under the Islamic rule of Khula.

The woman exhausted all avenues available to her in terms of the Islamic law ${ }^{33}$ and the husband refused to divorce the wife. The wife had no option but to approach the Islamic authorities ${ }^{34}$ for a decree of divorce. These authorities have as their point of departure, the principle of reconciliation and not dissolution of the marriage. The wife instituted her claim, and after five months was informed of a date for a hearing. This hearing was concluded in fifteen minutes, and after two months, the wife received a registered letter from the council stating there was

existing marriage has been terminated in terms of the Shari'ah. Thus the husband infringes upon the woman's rights as guaranteed in s 12(d) and s 18 of the Constitution.

28 The wife in this case, lived with her mother in law, brother in law, his wife and children.

29 See Rautenbach and Goolam (eds) Legal Pluralism 64.

30 A detailed analysis of the contributing factors leading to the irretrievable breakdown of the marriage falls beyond the scope of this article.

31 The wife requested a divorce, by trying to enter into an agreement of Khula, but the husband was not interested in co-operating. A detailed discussion on the Islamic law of divorce falls beyond the scope of this article. For a full discussion thereof see Rautenbach and Goolam (eds) Legal Pluralism 67-72.

32 See Rautenbach and Goolam (eds) Legal Pluralism 67.

33 The wife tried to negotiate a khula agreement, and also approached various Muslim authorities, such as the Jamiatul Ulama Transvaal.

34 Jamiatul Ulama Transvaal. 
not sufficient grounds to annul the marriage. ${ }^{35}$ Thus the marriage was still intact in terms of the Islamic law. The council required that the parties to the marriage reconcile, and resume living as husband and wife even though the parties had not had any contact of whatsoever nature with each other since November 2001, and even though a protection order has been granted in terms of the Prevention of Family Violence $\mathrm{Act}^{36}$ in favour of the wife.

The problem that the wife had is as follows:

a) The wife had to provide for her own maintenance and support; even though in terms of Islamic law ${ }^{37}$ this duty rested with the husband. He simply refused to maintain her, as well as divorce her. She had no legal footing to enforce this duty of support in a South African court.

b) She could not and will not be able to enter into another marriage contract with any other person unless and until the existing marriage is dissolved in terms of Islamic law and then completed her iddah period. ${ }^{38}$

c) She is not and presently does not enjoy any protection from the South African legal system with regards to obtaining an Islamic divorce; even though her fundamental rights have been and still are being infringed upon.

d) The woman in this example is being held hostage by her husband in direct conflict with the laws of Islam and the bill of rights as contained in the Constitution, yet she enjoys no protection at all.

35 Though the hearing was for fifteen minutes only, we are assured that the Islamic council spent many hours interviewing all related parties and forwarded documentation.

36 Prevention of Family Violence Act 116 of 1998.

37 See $\mathrm{n} 17$ above.

38 See Rautenbach and Goolam (eds) Legal Pluralism 71. 
Does a solution exist for this woman, or for any other Muslim women who wishes to obtain a divorce in South Africa?

It is unfortunate that the answer to this question has to be negative even though South Africans have vowed to live in an open and democratic society based on equality freedom and justice. ${ }^{39}$ At present, the non-recognition of Islamic family law is certainly not in line with the fundamental values of our new constitutional order, namely freedom, equality and human dignity. Furthermore, in respect of the Muslim female spouse, justice is not being done or seen to be done.

\section{The Draft Bill}

\subsection{Introduction}

In 2000 a bill was drafted by the South African Law Reform Commission. ${ }^{40}$ This legislation recognises the urgent and imperative need to redress inequalities and hardships faced by South African Muslims as a result of the non-recognition of Islamic family law. This act will recognise Islamic family law within a constitutional framework. ${ }^{41}$

\subsection{The effect of the bill}

The application of Islamic family law would ensure that Muslim females, who have registered their marriages in accordance with the criteria set down by the legislation, will be enabled to ensure that their male spouses fulfil their rights to maintenance during their iddah (waiting period after a divorce). It would allow

39 Preamble to the Constitution.

40 It is noted that there is a proposed draft bill of July 2003.

41 SALR Islamic Marriages and related Matters. 
them to apply to a South African court for dissolution which would be recognised $^{42}$ by all.

Thus the bill will have the following effect on a Muslim woman (the wife in our practical example) who wishes to obtain a divorce:

1. Her marriage will be recognised as a valid marriage;

2. The marriage will have to be registered within a 12 month period after the commencement of the act or within such time prescribed by the Minister in the Government Gazette;

3. The wife will be able to institute divorce proceedings in a court of law for Faskh; ${ }^{43}$

4. She will be able to claim maintenance from her husband as long as the marriage is still intact. ${ }^{44}$

The application of the Islamic family law will further result in the following benefits:

1. There will be a full record of Islamic marriages;

2. A coherent legal system to cater for the personal and religious beliefs of Muslims minorities due to which the inner conflict, which stems from the absence of such personal laws, would be limited or curbed and

42 The issues relating to the recognition of such a court require the positive role of Islamic legal institutions and Islamic clerics. It further demands that such a court be Islamically sound in its nature and in the judicial procedure.

43 Like divorce faskh also brings an end to the marriage. It literally means to annul a deed. It is decreed by the judge (Qadi) after the careful consideration of an application made to him by the wife. If the qadi is satisfied that the woman is prejudiced by a marriage, he will annul the marriage. For a full discussion on faskh see Doi Shari'ah 171 and Hamilton Hedaya.

44 Provided that, in terms of Islamic law and in reference to its legal schools, the wife is not classified as having violated her husband's rights and therefore fails to deserve maintenance on herself. 
3. A defined legal code in respect of insurance benefits to surviving spouses, social welfare benefits and all other related areas pertaining to the marriage contract.

\section{Conclusion}

The Draft Bill, particularly as regards divorce, will afford greater protection to the Muslim female spouse.

The Draft Bill, however, has not addressed one important issue. This relates to whether the court is authorised to grant a compelling order, to a husband, compelling him to divorce his wife. If the court is so authorised, then what penal action may be granted against the husband if he fails to abide with the court order? This will be applicable to the practical example referred to above, where it is clear that the marriage has irretrievably broken down and that the husband, out of spite and malice refuses to grant the wife a divorce, in contradiction to the laws of Islam. The court in Raik $v$ Raik, ${ }^{45}$ was faced with the situation where the defendant refused to grant a get ${ }^{46}$ to his wife. The court held that the parties to an agreement to grant a get must be held to it and an order for specific performance was granted. ${ }^{47}$ It is suggested that this decision be taken into account by the Law Commission when reviewing the Draft Bill.

In conclusion, it must be remembered that any legislation recognising Muslim marriages and related matters will have to stand the test of constitutionality before it will be accepted in South Africa. Furthermore, if the recognition of such an act is not acceptable to the Muslim community, the result will be mere paper law.

45 Raik v Raik 19932 SA 617 (W).

46 A get is a divorce bill employed by Jewish spouses to dissolve their marriage in accordance with their religious rites and customs. 
47 See also Blackbeard 1994 JCRDL 641-647. 


\section{Bibliography}

Azeem Women in Islam

Azeem SA Women in Islam Versus Women in The Judaeo-Christian

Tradition: The Myth \& The Reality (The Islamic Message Society 1995)

Blackbeard 1994 JCRDL

Blackbeard M "To get or not to get a Get"1994 (57:4) JCRDL 641-647

Cassim 1999 Codicillus

Cassim F "Understanding women's rights in Islam" 1999 Codicillus 1

Doi Shari'ah

Doi ARI Shari'ah (Ta Ha Publishers London 1984)

Ghazali Marriages in Islam

Ghazali I The Proper Conduct of Marriages in Islam (Al Baz Publishing Hollywood 1998)

Ghazali Qadaya al Mar'aa bin al Taqaleed al Rakida wal Wafida

Ghazali M Qadaya al Mar'aa bin al Taqaleed al Rakida wal Wafida $4^{\text {th }}$ ed (Dar Al Shorooq Cairo 1992)

Hamilton Hedaya

Hamilton C The Hedaya: Commentary on the Islamic Laws Vol IV Translation (Kitab Bhavan New Dehli 1985)

Hahlo Husband and Wife

Hahlo HR The South African Law of Husband and Wife (Juta Cape Town 1963)

Moosa $1999 D R$

Moosa N "Muslim divorce and the 1996 Divorce Amendment Act" 1999 DR 33 
Qur'an

Holy Qur'an

Robinson, Human and Boshoff Familiereg

Robinson JA, Human S and Boshoff A Inleiding tot die Suid-Afrikaanse

Familiereg (Printing Things Potchefstroom 2002)

Rautenbach and Goolam (eds) Legal Pluralism

Rautenbach C and Goolam NMI (eds) Introduction to Legal Pluralism in

South Africa: Part II Religious Legal Systems (Butterworths Durban 2002)

SALC Islamic Marriages and Related Matters

South African Law Reform Commission Project 59 Discussion Paper 101 on

Islamic Marriages and Related Matters (Pretoria 2001)

SALC Report on Islamic Marriages and Related Matters

South African Law Reform Commission Project 59 Report on Islamic

Marriages and Related Matters (Pretoria 2003)

Van der Vyver and Joubert Persone- en Familiereg

Van der Vyver JD and Joubert DJ Persone- en Familiereg $3^{\text {rd }}$ ed (Juta Cape Town 1985)

\section{Register of Cases}

Amod v Multilateral Motor Vehicle Accidents Fund (Commission for Gender

Equality Intervening) 19942 SA 1319 (A)

Ismail v Ismail 19831 SA 1006 (W)

Juleiga Daniels v Robin Grieve Campbell NO (unrep CPD case no 1646/01 of 24

June 2003)

Raik v Raik 19932 SA 617 (W)

Ryland v Edros 19972 SA 690 (C) 


\section{Register of Legislation}

Constitution of the Republic of South Africa 1996

Divorce Act 70 of 1979

Divorce Amendment Act 95 of 1996

Intestate Succession Act 81 of 1987

Maintenance of Surviving Spouse Act 27 of 1990

Prevention of Family Violence Act 116 of 1998

\section{Register of Internet resources}

Alinaam http://www.alinaam.org.za/misc/mpl-const.htm 19 May

Alinaam [Found on Internet] http://www.alinaam.org.za/misc/mpl-const.htm

[Date of use 19 May 2003]

Islamic Society http://www.unn.ac.uk/societies/islamic/about

/women/judochri.htm 19 May

Islamic Society [Found on Internet]

http://www.unn.ac.uk/societies/islamic/about /women/judochri.htm [Date of use 19 May 2003]

SALC Islamic Marriages and Related Matters (Issue Paper 15) http://www.law.wits.ac.za/salc/issue/ip15.pdf 1 Nov South African Law Reform Commission Islamic Marriages and Related Matters (Issue paper 15: Project 59 May 2000) [Found on Internet] http://www.law.wits.ac.za/salc/issue/ip15.pdf [Date of use 1 Nov 2004] 